\title{
[Rec.:] My, regionaliści. W stronę autowizerunku, red. Damian Kasprzyk, Fundacja Ważka, Wrocław 2018, ss. 198
}

Pomysłodawcą i redaktorem naukowym prezentowanego wydawnictwa jest Damian Kasprzyk, młody naukowiec z Instytutu Etnologii i Antropologii Kulturowej Uniwersytetu Łódzkiego, związany aktywnością naukową, jako sekretarz, z Interdyscyplinarnym Zespołem Badania Wsi UŁ. Dziewięć lat temu opracował autorski, wówczas pionierski w skali kraju, projekt badawczy, którego celem miało być uzyskanie - jak ustalił - odpowiedzi „na pytania kim są [regionaliści - przyp. A.L.], dlaczego się za takich uważają, jak postrzegają swoją rolę, co jest dla nich cenne, jakie są źródła inspiracji dla rozmaitych działań na rzecz najbliższego otoczenia lub choćby emocjonalnego doń stosunku”.

Traktując z należytą uwagą problematykę rozwijającego się ruchu regionalistycznego, a raczej coraz bardziej dynamicznych ruchów regionalistycznych, D. Kasprzyk oryginalnie zauważył, że: „W dyskusji poświęconej znaczeniu regionalizmu polskiego w kształtowaniu tożsamości społeczno-kulturowej naszego społeczeństwa, brakuje refleksji związanej z etosem regionalisty, rozumianej jako system wartości i postaw. Uzupełnieniem tej luki byłby zbiór wypowiedzi regionalistów, który zmierzałby do ukazania autowizerunku tej specyficznej grupy społeczników, cieszących się uznaniem środowiska”.

Zamysł uzyskania refleksji określających system wartości, a może nawet tożsamość społeczno-kulturową regionalisty, nawiązuje do chęci odpowiedzi na zasadnicze pytania jakie stawia antropologia kulturowa: co tworzy tożsamość współczesnego człowieka? co określa jego idee i możliwości twórczego funkcjonowania w społeczeństwie? Przekonanie, że właśnie regionaliści stanowią tę grupę autorytetów, która w tzw. terenie nadaje ton przeobrażeniom środowiskowym i wpływa na system wartości i perspektywy rozwoju miejscowego społeczeństwa, legło u podstaw wywołania owej refleksji.

Przy tym trzeba zdawać sobie sprawę z tego, że polskie regiony, to często jeszcze tzw. wewnętrzne peryferia, tereny zaniedbane i zacofane cywilizacyjnie. Nie mają jeszcze szczęścia do swoich regionalistów. Czekają na nich szczególnie obszary wiejskie, które - jak słusznie zauważa prof. Izabella Bukraba-Rylska (Instytut Rozwoju Wsi i Rolnictwa PAN) - są „quasi-kolonią” dla reszty kraju. Bez zaangażowanych regionalistów trudno będzie opracować dobry plan rozwoju tych terenów, w przewadze wiejskich, sięgający po wzorce europejskie w ekonomice i jednocześnie wyzwalający potencjał społeczno-kulturowy polskiej wsi. Być może recenzowane opracowanie zachęci do podjęcia działań przez animatorów pozostających dotychczas poza ruchami regionalistycznymi.

Już pierwsza praca, która powstała w wyniku działań D. Kasprzyka („Ja - regionalista. Refleksje, stanowiska, komentarze”, Łódź 2010, ss. 135), jak i sam projekt badawczy, uzyskały wysokie oceny naukowców i samych regionalistów. Między innymi wybitna badaczka wsi i kultury ludowej z Instytutu Rozwoju Wsi 
i Rolnictwa, prof. Maria Wieruszewska, wyraziła ten pogląd w 2011 r. w kwartalniku „Wieś i Rolnictwo” [http://kwartalnik.irwirpan.waw.pl/dir_upload/photo/ 7c6a96255eab7284e27b41630551.pdf (dostęp: 31 I 2019)].

W następnych latach D. Kasprzyk dalej prowadził badania według specjalnie opracowanych odezw do regionalistów, pełniących funkcję dyspozycji do wywiadu swobodnego. Dając swoistym interlokutorom możliwości pełnej i nieskrępowanej wypowiedzi na piśmie, zredagował kolejne opracowania: „Kim jesteś regionalisto? Sylwetki, opinie, diagnozy” (Łódź 2012, ss. 272) oraz „Być regionalistą. Inspiracje, autodefinicje, perspektywy” (Łódź 2014, ss. 276).

Książka „My, regionaliści” jest więc już czwartą pozycją wydawniczą w ciągu ostatnich lat, stanowiąc pokłosie pomysłu, którego zresztą szczegóły przedstawił Autor w artykule „Regionaliści sami o sobie. Rzecz o pewnym projekcie badawczym, jego realizacji i wstępnych wnioskach” [,Zeszyty Wiejskie”, Z. XX, 2014, s. 211-226]. Tym samym konsekwentnie realizuje zdobywanie materiałów źródłowych, niezbędnych do określenia cech mentalnych zwolenników „małej ojczyzny”, horyzontów ich wiedzy i wrażliwości społecznej, a zarazem jakości patriotyzmu, w którym - jak się okaże - miłość do regionu nie przekreśla, a wręcz wzmaga szacunek do dużej Ojczyzny i całego świata. Okaże się także, że region, z którego są dumni, to dla nich nie „zapyziała” prowincja, ale ważna i wartościowa część Polski i Europy, w której granice administracyjno-polityczne zdają się tracić swoje dezintegrujące właściwości na rzecz zespalającej wielokulturowości wzajemnie doceniających się i uzupełniających regionów.

Książkę otwiera tekst „Regionaliści - szkic do portretu” autorstwa redaktora naukowego. Kasprzyk bardzo jasno i precyzyjnie ustala cel opublikowanego zbioru wypowiedzi regionalistów, stwierdzając, że „to wydawnictwo ma dopiero pomóc ustalić kim są, lub raczej kim bywają, regionaliści w ponowoczesnym świecie”.

Dalekosiężny cel - w intencjach oczywisty - niech D. Kasprzyk wybaczy, jawi się w tym sformułowaniu nieco pretensjonalnie. Dlatego, doceniając ambicje badawcze naukowca, pozwolę sobie na drobną dygresję, która zmierza do uznania tzw. ponowoczesności za fantasmagorię urzekającą szczególnie młodych naukowców, przejętych ideami tak wybitnych filozofów, jak chociażby J. Derrida („teoria dekonstrukcji”) czy Z. Baumana (,świat płynnej nowoczesności”). Jednakowoż warto też wiedzieć, iż w polskiej humanistyce pojawiły się stanowiska zgoła inaczej przedstawiające ową „ponowoczesność”. Na przykład wybitny filozof Bronisław Łagowski głosił pogląd, że „postmodernizm to filozofia półinteligencji, która to kategoria zresztą się rozrasta (...) są to rzeczy zupełnie powierzchowne, absolutnie nieprzemyślane”. Podobnie inny uczony, antropolog kultury, Ludwik Stomma swego czasu nie ukrywał, że „postmodernizmu nie ma i nigdy nie było. Jest to pseudofilozoficzny twór, w którym miesza się wszystko ze wszystkim (...)”.

Czy więc regionaliści „bywają w ponowoczesnym świecie?” Może kiedyś będą... Ich ruchy społeczne zawsze odnoszą się do konkretnego świata „małych ojczyzn”. Polskie regiony to często świat prowincji, obszarów wiejskich, którym - jak już wyżej zaznaczono - jeszcze dość daleko do nowoczesnej cywilizacji, 
a co dopiero do ponowoczesności. Poza tym idee postmodernizmu wypełniają hasła globalizmu, ogarniającego swym zasięgiem przede wszystkim państwa wysokiego rozwoju przemysłowego, zlokalizowane głównie w Europie Zachodniej i Ameryce Północnej. Tymczasem takim swoistym antidotum na nadmiernie ogarniający nas globalizm, pozbawiający narody, grupy etniczne i w ogóle społeczności regionalne własnej tożsamości społeczno-kulturowej, są właśnie równolegle rozwijające się ruchy alterglobalistyczne, których bodaj najbardziej wpływowym liderem jest regionalizm.

Wobec powyższego jestem skłonny powiązać aktywność społeczną regionalistów, określającą ich tożsamość bardziej z konkretną „małą ojczyzną” niż z ,ponowoczesnym światem”. Niemniej jednak nie wyklucza to wpływu postaw i działalności tych ludzi na różne zjawiska społeczno-kulturowe i gospodarcze świata, który jednak niezależnie od naszej woli, coraz bardziej ulega globalizacji pod wpływem postępu naukowo-technicznego.

Samo podejście metodologiczne określane jako „ponowoczesność” zapewne jest i będzie atrakcyjne w kreowaniu myśli wielkiej filozofii. Natomiast regionalizm może dalej realizować swoje idee „tu i teraz”, z konkretnym pożytkiem dla całego społeczeństwa.

Regionaliści żyją w swoich regionach, do których przynależność świadomie wybrali, nie pozbawiając się jednoczesnej przynależności do swojego państwa, kontynentu i świata. Pragną aktywnie funkcjonować w „małej ojczyźnie”, pielęgnując wartości tradycyjne, ale dążąc także do otwarcia się na nowoczesność i postęp cywilizacyjny. Właśnie tej idei są świadomie wierni autorzy dzielący się wiedzą i miłością do swojego regionu na łamach książki „My, regionaliści”.

W ogóle jednak D. Kasprzyk, dysponując najnowszymi i poprzednimi opracowaniami, zawarł w „Szkicu...” nowatorskie ustalenia metodologiczne, polegające na wypracowaniu typologii „,przestrzeni aktywności i postaw” regionalistów, którą wydobył poprzez swojego autorstwa „Apel do regionalistów”. Wszystkie opublikowane w pracy teksty to właśnie odpowiedzi na ów „Apel”, dzięki któremu powiodło się wyodrębnienie sześciu metaforycznych „krain”, czyli „przestrzeni aktywności i postaw, które regionaliści współtworzą i pielęgnują, na równi z krainami kulturowymi, historycznymi, etnograficznymi czy też administracyjnymi”. Są to w kolejności: 1) Kraina Tożsamości, 2) Kraina Wychowania, 3) Kraina Słowa, 4) Kraina Pamięci, 5) Kraina Współpracy i 6) Kraina Tolerancji. W ten sposób syntetycznie ustalił system wartości wynikającej z analizy wypowiedzi zapisanych w całym tomie. Znalazł i wyeksponował refleksje aksjologiczne zaświadczające o wierności regionalistów wobec „krainy ducha”. Odwołał się do nich, między innymi odnalazł je w wypowiedzi Marka Gradonia, prezesa Stowarzyszenia Miłośników Historii Szczekocina i Okolic, „(...) że największym zagrożeniem dla regionalizmu jest »pogoń za dobrami doczesnymi «”, albo w ustaleniu Jadwigi Marii Dudy, nauczycielki i muzealniczki z Wieliczki, „(...) że regionalista »jest wzorem miłości, sługą sług «”.

Recenzowana praca zintegrowała w swoim składzie autorskim aktywnych i refleksyjnych animatorów życia społeczno-kulturalnego z terenów całej Polski. 
Reprezentują oni kilka najnowszych pokoleń naszego społeczeństwa; od urodzonych przed II wojną światową, aż do tych, którzy znaleźli się na świecie wraz z początkami III Rzeczypospolitej w 1989 roku. Wszyscy są dobrze wykształceni, niektórzy nawet z doktoratem. Wśród nich przeważają humaniści - historycy i pedagodzy, nauczyciele i działacze wykazujący się znaczną aktywnością w swoim środowisku. W tym miejscu należy dodać, że podobny skład autorski społeczno-zawodowy, występował również w poprzednich opublikowanych zbiorach, w których swoją wiedzą i opiniami dzielili się tej miary uczeni, co prof. prof. ks. Henryk Skorowski, Józef Borzyszkowski i Cezary Obracht-Prondzyński.

Cały tom zawiera 25 tekstów, które nawiązując do jego idei, formułują refleksje autorów regionalistów w formach nieco zróżnicowanych. Występują w nim artykuły o zacięciu naukowym, zawierające teoretyczne rozważania, ale w ogromnej przewadze są tutaj osobiste refleksje, chociaż także poparte odwołaniem się do literatury regionalnej, niekiedy własnego autorstwa. Wszystkie te wypowiedzi zaświadczają o emocjonalnym i pełnym troskliwej miłości stosunku do własnej „małej ojczyzny”, która dzięki temu staje się ojczyzną osobistą, pełniącą jakby funkcje domu rodzinnego.

Cechą charakterystyczną niektórych wypowiedzi jest utożsamianie regionalizmu z krajoznawstwem, czy przynajmniej szukanie bliskości między tymi ruchami społecznymi (Por. A. Ruszkowski, Moja droga do regionalizmu. . czy krajoznawstwa?). Jest to podejście ze wszech miar słuszne i inspirujące do podjęcia atrakcyjnej społeczno-kulturalnie działalności. Zresztą nawiązuje do genezy regionalizmu jako ruchu społecznego, który został zainaugurowany przez działaczy Polskiego Towarzystwa Krajoznawczego z Aleksandrem Patkowskim na czele w początkach II Rzeczypospolitej. Krajobraz, który w potocznym rozumieniu kojarzy się z naturą i pięknem przyrody nieskażonej nadmiernym rozwojem cywilizacyjnym, dla obu tych ruchów społecznych jest istotną przestrzenią - wartością ich aktywności. Może dlatego ich regionalizm w zasadzie swoje działania sytuuje poza ośrodkami miejskimi i przemysłem, bliżej wsi i rolnictwa, jakby podzielając opinie, pojawiające się już w czasach antycznych, które nie były zbyt pochlebne dla miejskich skupisk ludności. Uważano, że oddalają one ludzi od Boga i - metafizycznie ujmując - „zielonych dolin, pachnących kwiatów, tańca i śpiewu oraz ciągłej uczty” na łonie przyrody.

Autorzy prezentowanego tomu szczególną estymą darzą środowisko wiejskie, nie wstydząc się swojego pochodzenia, a wręcz podkreślając swój związek z gospodarstwem rodzinnym i wsią. W tym miejscu mogę się odnieść do refleksji Marii Madej, nauczycielki z Towarzystwa Miłośników Ziemi Zatorskiej, która pisze: „Wieś mam we krwi. Na wsi się urodziłam i wyrosłam (...). Nigdy nie pragnęłam mieszkać w mieście, gdzie ciasno i duszno, a mieszkanie w blokowiskach uznawałabym za więzienie”.

Nie chciałbym specjalnie wyróżniać któregoś z 25 autorów regionalistów, którzy kompetentnie i jednocześnie refleksyjnie wypowiedzieli się na temat swojej „,małej ojczyzny” oraz w ogóle znaczenia i celów coraz bardziej powszechnego ruchu społecznego przez nich reprezentowanego. Niewątpliwym walorem recenzowanej pracy jest i to, że dała ona możliwość wypowiedzi kobietom - aż 1/3 
spośród wszystkich autorów, co rzadko zdarza się w tego typu wydawnictwach. Dlatego można podnieść, że piękniejsza część całej populacji polskich regionalistów nadaje temu ruchowi społecznemu specjalny charakter wrażliwości społecznej i tak pożądanego równouprawnienia płci. Wzruszające potwierdzenie powyższej uwagi odnajdziemy w mądrej myśli Adriany Jarosz, nauczycielki, bibliotekarki i poetki z Izbicka (woj. opolskie): „Jeśli chce się odkryć świat, trzeba najpierw poznać najbliższą okolicę".

Wszyscy autorzy pracy zbiorowej „My, regionaliści”, czy to profesjonalnie, czy amatorsko wyrażający poglądy na temat ,autowizerunku”, odkrywają wyraźnie zasadnicze aksjomaty swojej tożsamości, tak jak cytowana A. Jarosz. W ich systemie wartości miłość do „małej ojczyzny” nie wyklucza otwartego i humanistycznego stosunku do problemów świata. Pozwala więc na aktywne życie ze świadomością, że „Regionalizm to miłość do ziemi i ludzi” (Bartłomiej Grabowski, pisarz i historyk z Nadgoplańskiego Towarzystwa Historycznego).

Książka regionalistów i o regionalistach została wydana, jak zresztą poprzednie prace z tego cyklu, bardzo starannie i estetycznie, przez Fundację Ważka z Wrocławia. Jej atrakcyjność edytorską znacznie wzmacniają zamieszczone w niej zdjęcia, przeważnie zrobione przez samych autorów. Natomiast poziomem i pięknem imponują, publikowane na okładce i stronach parzystych jako wypełnienie, fotografie Barbary Ałaszewskiej, artystki amatorki z Piotrkowa Trybunalskiego.

Ponadto praca została zaopatrzona w ważny dla wzmocnienia jej funkcji poznawczych, tzw. aparat pomocniczy, to znaczy „Noty o autorach”, „Apel do regionalistów”, „Bibliografię przedmiotową” oraz syntetyczne, jednostronicowe streszczenia pracy zapisane w sześciu tzw. językach konferencyjnych, m.in. chińskim i dodatkowo w jęz. niemieckim. Lektura książki byłaby jeszcze bardziej przyswajalna, gdyby zaopatrzyć ją w indeksy: osobowy i nazw geograficznych.

Na koniec jeszcze zauważę, że dzięki wydaniu drukiem kolejnego, już czwartego tomu wypowiedzi (w sumie ponad 100 regionalistów), udało się zgromadzić potężny materiał empiryczny, który z powodzeniem może być wykorzystany do napisania nowatorskiej monografii na temat tożsamości społeczno-kulturowej animatorów polskiego regionalizmu, skupionych różnorodnymi działaniami w wielo- i jednoczynnikowych regionach naszego kraju - swoich „małych ojczyznach”. Realizacji tego autorskiego pomysłu życzymy D. Kasprzykowi, który tym samym ciągle się rozwijając, wkroczy efektywnie na szlak w pełni samodzielnej drogi naukowej.

Andrzej Lech

Adres mailowy autora: jendrol1@interia.pl 